This is the version of a forthcoming article accepted for publication in Journal of Post Keynesianism Economics published by Taylor \& Francis: http://www.tandfonline.com/loi/mpke20

Accepted version made available via SOAS Research Online: http://eprints.soas.ac.uk/23081/

\title{
Multilateralism and Military Keynesianism: Completing the Analysis
}

\author{
Jan Toporowski, SOAS University of London
}

\begin{abstract}
Kalecki's analysis of military Keynesianism highlights the difficulties of managing aggregate demand in one country, without coordination with trading partners. Military Keynesianism is effective as a means of reflation because, unlike civilian public works, it induces similar expenditure by political rivals. In this way it overcomes some of the trade difficulties that arise if aggregate demand expands in only one country.
\end{abstract}

Key words: Kalecki, military Keynesianism, aggregate demand management.

JEL Classification: B3, E2, E3, E6, H5.

James M. Cypher's paper on 'The origins and evolution of military Keynesianism in the United States' is a welcome account of some themes that circulate through the discussion of this topic. But, in its theoretical reflections, the paper overlooks some fundamental contributions, most notably by Paul Sweezy (Baran and Sweezy 1966, chapter 7; Sweezy 1981 - see also Szlajfer 1984 and 'Notes from the Editors', Monthly Review July-August 2016), Ron Smith (Smith 1977 and 1980) and Michał Kalecki. Among these authors Kalecki stands out because his understanding of military Keynesianism goes beyond the contribution that military expenditure can make to aggregate demand, to a critical appreciation of the political and economic difficulties of the aggregate demand management that commonly passes for Keynesianism. Those political and economic difficulties also reach beyond the 
This is the version of a forthcoming article accepted for publication in Journal of Post Keynesianism Economics published by Taylor \& Francis: http://www.tandfonline.com/loi/mpke20

Accepted version made available via SOAS Research Online: $\underline{\text { http://eprints.soas.ac.uk/23081/ }}$

political business cycle, that Professor Cypher has as Kalecki's contribution to his discussion of military Keynesianism.

\section{The limitations of Keynesianism ...}

Professor Cypher writes that 'Military Keynesianism arose from historically unique circumstances that allowed for policy coherence and broad consensus between large industrial interests of the state and the working class for a limited period of time.' (Cypher 2016, p. 463). In focusing on the political circumstances of the United States at the time, Professor Cypher neglects the role of military Keynesianism as a multilateral coordinating mechanism of Keynesian fiscal policy and the need for such a mechanism except perhaps in the United States whose government has used such policy on the greatest scale.

Kalecki's consideration of military Keynesianism goes back to his commentaries on perhaps the first and most common example of such Keynesianism, the rearmament of Germany in the 1930s. But even before Hitler's assumption of power, Kalecki had identified the flaw in the notion that fiscal stimulus, as a policy option available to all governments, offers a way out of economic depression. In his paper 'Is a "Capitalist" Overcoming of the Crisis Possible', published in the Polish magazine The Socialist Review (before it was shut down by the authorities at the end of 1932), Kalecki described fiscal stimulus as:

'... a certain form of inflation consisting of individual states, or groups of states, starting up major public-investment schemes, such as construction of canals or roads, and financing them with government loans floated on the financial market, or with special governments credits drawn on their banks of issue (i.e., their central banks - JT). This kind of operation could 
This is the version of a forthcoming article accepted for publication in Journal of Post Keynesianism Economics published by Taylor \& Francis: http://www.tandfonline.com/loi/mpke20

Accepted version made available via SOAS Research Online: http://eprints.soas.ac.uk/23081/

temporarily increase employment, though on the other hand it would retard automatic "natural" adjustment processes which might lead to overcoming the crisis. Besides this, if it were to be carried out on a large scale, it would have to be coordinated by an international agreement of the individual capitalist governments, which, given today's quarrelling imperialisms, is almost out of the question.' (Kalecki 1932a, p. 53).

The "'natural" adjustment processes' to which Kalecki referred were the elimination of excess capacity through market competition, which forces companies to shut down unused factories, and concentrate production in under-utilised factories. Such reduction in capacity makes firms more willing to invest as demand rises. As for the need for international agreements to coordinate such fiscal stimulus, Kalecki explained this in an article in the same journal shortly afterwards, where he also showed the limitations of the kind of 'credit inflation' that is the preferred policy of choice among European and North American elites today:

'... a more liberal supply of credit by the central bank, may be of minor significance only, when the business crisis is a deep as at present. Entrepreneurs will not, as a rule, invest the newly received credits because easier terms of credit will not induce any investor to build a factory that will have no chance of finding a market for its products. New credits will be used rather to pay back the old ones and the surprised creditors will bring their repaid credits back to banks thus happily closing the circle.'

Fiscal policy, according to Kalecki, does have the possibility of expanding demand. But even this has obvious limitations, most notably an exchange rate crisis and price inflation:

‘... massive public works ... would result in increased employment. However, even such an intervention could be effective only if it were undertaken in a closed economy, e.g., in the 
This is the version of a forthcoming article accepted for publication in Journal of Post Keynesianism Economics published by Taylor \& Francis: http://www.tandfonline.com/loi/mpke20

Accepted version made available via SOAS Research Online: http://eprints.soas.ac.uk/23081/

capitalist system as a whole, embracing the whole world, where there is one exchange (rate) only and no tariff barriers... Fiscal inflation carried out on a broader scale in one country alone ... must cause disturbances in the rate of exchange. A rise in local output requires increased supplies of foreign raw materials and imports ... At the same time, together with employment, domestic prices rise, which restricts exports. Consequently the balance of payments deteriorates, an outflow of gold and foreign exchange follows and the exchange rate falls...... These processes will set in earlier because, in expectation of them, foreign capital will withdraw and local capitalists will purchase foreign exchange thus accelerating devaluation. This, in turn, will distort the fiscal inflation process because a rise in prices of foreign raw materials will add to a general price rise until the symptoms of hyperinflation ... appear.' (Kalecki 1932b, pp. 175-176).

The way to overcome this difficulty is for governments to coordinate their efforts at fiscal stimulus. In this way, as aggregate demand expands among trading partners, all countries import more and, as a consequence, all of them export more. But, as already indicated, Kalecki was sceptical about this possibility and reiterated, 'a necessary condition for fiscal inflation to be effective is an international agreement of the capitalist powers, which is, of course, totally utopian.' (Kalecki 1932b, p. 176).

At the height of the Second World War, international economic coordination between the world powers did come back onto the agenda at Bretton Woods in 1944. But even here Kalecki correctly recognised that, without a distribution of capital that would allow full employment in all countries and balanced trade, those trade imbalances would be regarded as symptoms of the 'manifest unsoundness' of the state of aggregate demand that brought about the full employment. To this irrational, but politically convenient, apprehension would be added the fear of foreign indebtedness, as trade imbalances were cleared with automatic 
This is the version of a forthcoming article accepted for publication in Journal of Post Keynesianism Economics published by Taylor \& Francis: http://www.tandfonline.com/loi/mpke20

Accepted version made available via SOAS Research Online: $\underline{\text { http://eprints.soas.ac.uk/23081/ }}$

adjustments of net foreign debt stocks (Kalecki 1946). The founding agenda of the European Union includes the coordination of the economic policies of member governments. But this coordination has not been going well in Europe in recent years, precisely because of anxieties over debts ${ }^{1}$.

\section{2. ... Overcome by military Keynesianism}

In Kalecki’s view, military Keynesianism is not just another form of government expenditure more congenial to employers because, unlike, say, health or education services, it does not enter into competition with private sector provision, but pays private sector suppliers to 'waste' resources, in Veblen's vivid description (Veblen 1904, pp. 64-65). Military

Keynesianism has the advantage over civilian Keynesianism that military expenditure and bellicose declarations force governments in neighbouring countries into emulatory rivalry. This has some of the benefits of internationally coordinated civilian Keynesianism, leveraging in imperialist quarrels to create employment. Kalecki observed the rearmament of Germany and Japan, as a form of military Keynesianism (Kalecki 1932b). However, he noted that this kind of Keynesianism does little for consumption and such 'roads to glory' lead to war.

Following the Second World War, one of the functions of the military alliances, the North Atlantic Treaty Organisation (NATO), and the Warsaw Pact, has been to co-ordinate military

\footnotetext{
1 Anyone who doubts the power of foreign debt to intimidate even economists and policy-makers who claim special knowledge of international finance need only look through the discussion of the Greek crisis since 2010, or observe the 'Balcerowicz meter' in the centre of Warsaw, put up by a former finance minister and governor of the Polish central bank ostensibly to inform Polish citizens of how much debt their government is incurring on their behalf, to see how little reason percolates into discussions of foreign debt.
} 
This is the version of a forthcoming article accepted for publication in Journal of Post Keynesianism Economics published by Taylor \& Francis: http://www.tandfonline.com/loi/mpke20

Accepted version made available via SOAS Research Online: $\underline{\text { http://eprints.soas.ac.uk/23081/ }}$

expenditure with, in the case of NATO, targets for military expenditure by member governments. Kalecki did not comment on this aspect of activity in the Soviet bloc. But he clearly understood the coordinating function of military Keynesianism in capitalism.

In November 1955, Kalecki gave three lectures on 'The Impact of Armaments on the Business Cycle after the Second World War' at the social science university of the ruling party in Poland ${ }^{2}$. The lectures became widely available posthumously with their publication in the Collected Works of Michat Kalecki. They are wide-ranging and include discussion of inflation, deficit financing and credit. On the basis of a four-sector model of a capitalist economy (investment, workers' consumption, capitalists' consumption, and armaments) Kalecki showed how deficit financed military expenditure adds to profits (Kalecki 1955). In answer to a student's question as to whether civilian expenditure could substitute for armaments, Kalecki answered as follows:

'This is a very good question which gives an opportunity to explain the essence of the problem. If one could devise public works equally as unproductive as armaments, they would have similar consequences. It is obvious, however, that the construction of schools, hospitals and even roads is of limited scale. However, the situation is entirely different as regards productive public works, since such constructions compete with the private sector and reduce the rate of capitalist profits, which obviously has a negative impact on private investment. Consequently, the economic effect of such public works will be weaker in the long run, and, besides this, will draw immediate political opposition from the monopolies damaged (by such competition). For instance, to this day in the USA attacks continue on the dams and power

\footnotetext{
${ }^{2}$ The Institute of Social Sciences at the Central Committee of the Polish United Workers' Party, where Kalecki's friend Oskar Lange ran the programme in Political Economy.
} 
This is the version of a forthcoming article accepted for publication in Journal of Post Keynesianism Economics published by Taylor \& Francis: http://www.tandfonline.com/loi/mpke20

Accepted version made available via SOAS Research Online: http://eprints.soas.ac.uk/23081/

plants built during the New Deal under the public works programme. Armaments play a specific role precisely because they are unproductive...' (Kalecki 1955, p. 580-581).

In his lectures, Kalecki made the assumption of a closed economy, which was convenient, since the specific example that he was looking at was that of the United States, whose foreign trade position has little impact on its domestic economy. His consideration of the open economy effects of armaments expenditure came in a later paper on 'Economic Aspects of West German Rearmament'. Here he noted the internationally-coordinated aspect of postWar German rearmament: 'Unlike Hitler's, the Adenauer regime bases its military strategy on close collaboration with the whole capitalist camp. The key to the economic role of militarization of West Germany must also be sought in its indirect impact on the economic situation of that entire camp, which in turn influences the economic situation of West Germany.' Kalecki went on to argue that German exports had benefitted from the rearmament effort of the Western alliance: '... the expansion of West German exports, which has continued for a number of years rests on ... (among other factors) a high level of economic activity (that) has prevailed in the capitalist world one of whose mainstays has been the armaments programme of NATO, in particular that of the United States. As a result of this ... the demand for machinery as well as chemicals, West Germany's basic export products was high and rising... (But) the export efforts of West Germany's main competitors on the world market for machinery were weakened by the absorption of a large part of their respective export capacity by armaments production...'

'In other words, its production structure and costs have facilitated the expansion of West German exports on the world market where the situation has been favourable to a considerable extent because of the armaments programme of the capitalist camp. Armaments stimulated the economic activity of the capitalist world on the one hand, and they checked to 
This is the version of a forthcoming article accepted for publication in Journal of Post Keynesianism Economics published by Taylor \& Francis: http://www.tandfonline.com/loi/mpke20

Accepted version made available via SOAS Research Online: http://eprints.soas.ac.uk/23081/

some extent the trade expansion of the main exporters of machinery, on the other hand'.(Kalecki 1962, p. 405)

In this article, Kalecki considered the possibility of disarmament and replacing military expenditure with development projects in poorer countries, a new priority in the United Nations at the time and an idea that gathered support in the 1980s during the Third World Debt Crisis. 'But even if such a conversion of armament production were fully effected, the underdeveloped countries would then receive machinery from the former arms producers in such quantities that West German exports could not but be seriously hurt.' The link with the export trade was an ambiguous one: 'Armaments create a favourable position for West German exports. But, since West Germany must in turn arm itself, its export efforts will suffer as well.'(Kalecki 1962, p. 406)

This was not necessarily to the advantage of industry elsewhere in Europe: 'The British harboured the cynical dream that the armament of West Germany would paralyse its exports of machinery, thus enabling them to take over some Germany's markets. But, as often happens, this hope proved to be short-lived. The Germans outsmarted the British. True, they improved somewhat Britain's balance of payments; they did so, however, not by slowing down the expansion of their exports and surrendering their markets, but by directing arms orders to Great Britain, obtaining important political concessions in return.'(Kalecki 1962, p. 407).

\section{Conclusion}


This is the version of a forthcoming article accepted for publication in Journal of Post Keynesianism Economics published by Taylor \& Francis: http://www.tandfonline.com/loi/mpke20

Accepted version made available via SOAS Research Online: http://eprints.soas.ac.uk/23081/

In an article that was published in the New York Times in 1973, Paul Samuelson wrote that military spending and wars were no longer necessary to stimulate the economy, since Keynesian economists knew how to manage it on a peacetime basis, guaranteeing full employment and rapid economic growth (Samuelson 1973). The experience of military Keynesianism in the twentieth century is a sobering reflection on what is widely regarded among radical economists as the 'golden age' of capitalism in the twentieth century. As Kalecki's writings on the subject show, this overlooks the need for economic (and financial) coordination necessary to avoid macroeconomic imbalances. Military Keynesianism solves in part the coordination problem that is the main stumbling-block for civilian Keynesianism in medium-sized and smaller economies.

Kalecki was not alone in his view. There are many similarities between his analysis and that of Paul Sweezy, in particular their common view that military Keynesianism is expedient precisely because of the limitations of more socially useful Keynesianism. Shortly after Kalecki died, Paul Sweezy published through Monthly Review Press a small collection of Kalecki’s papers on military Keynesianism (Kalecki 1972).

Finally, it is worth pointing out the paradox that the United States, whose government has orchestrated military Keynesianism in the twentieth century, is also the one country that least needs to resort to this form of Keynesianism because of the status of its reserve currency and the scale of its domestic market, which makes it independent of foreign trade. This last circumstance had already been noted in Kalecki in 1932. (Kalecki 1932b). It is, however, doubtful that this was what brought Samuelson to his optimistic conclusion. 
This is the version of a forthcoming article accepted for publication in Journal of Post Keynesianism Economics published by Taylor \& Francis: http://www.tandfonline.com/loi/mpke20

Accepted version made available via SOAS Research Online: $\underline{\text { http://eprints.soas.ac.uk/23081/ }}$

\section{Acknowledgement}

I have greatly benefitted from my discussion of Kalecki’s work with Joseph Halevi.

\section{References}

Baran, P.A., and Sweezy, P.M., (1966) Monopoly Capital An essay on the American Economic and Social Order New York: Monthly Review Press.

Cypher, J.M., (2016) 'The origins and evolution of military Keynesianism in the United States' Journal of Post-Keynesian Economics Vol. 38, No. 3, Winter/Spring pp. 449-476.

Kalecki, M., (1932a) 'Is a "Capitalist” Overcoming of the Crisis Possible?' in J. Osiatyński (ed.) Collected Works of Michat Kalecki Volume I Capitalism: Business Cycles and Full Employment Oxford: The Clarendon Press 1990.

Kalecki, M., (1932b) 'Inflation and War' in J. Osiatyński (ed.) Collected Works of Michat Kalecki Volume VI Studies in Applied Economics 1927-1941 Oxford: The Clarendon Press 1996.

Kalecki, M., (1946) 'Multilateralism and Full Employment' in J. Osiatyński (ed.) Collected Works of Michat Kalecki Volume I Capitalism: Business Cycles and Full Employment Oxford: The Clarendon Press 1990.

Kalecki, M., (1955) 'The Impact of Armaments on the Business Cycle after the Second World War' in J. Osiatyński (ed.) Collected Works of Michat Kalecki Volume II Capitalism: Economic Dynamics Oxford: The Clarendon Press 1991.

Kalecki, M., (1962) 'Economic Aspects of West German Rearmament' in J. Osiatyński (ed.) Collected Works of Michat Kalecki Volume II Capitalism: Economic Dynamics Oxford: The Clarendon Press 1991.

Kalecki, M., (1972) The Last Phase in the Transformation of Capitalism New York: Monthly Review Press.

'Notes from the Editors' (2016) Monthly Review July-August, Vol. 68, No. 3.

Samuelson, P.A. (1973) 'Taking Stock of the War' New York Times 14 March.

Smith, R.P., (1977) 'Military Expenditure and Capitalism' Cambridge Journal of Economics, Vol 1, pp 61-76.

Smith, R.P., (1980), 'Military Spending and Investment in OECD Countries, 1954-1973', Journal of Comparative Economics, 4, pp.19-32

Sweezy, P.M., (1981) 'Competition and Monopoly' in Four Lectures on Marxism New York: Monthly Review Press.

Szlajfer, H., (1984) 'Waste, Marxian Theory, and Monopoly Capital: Towards a New Synthesis' in J.B. Foster and H. Szlajfer (eds.) The Faltering Economy The Problem of Accumulation under Monopoly Capitalism New York: Monthly Review Press. 
This is the version of a forthcoming article accepted for publication in Journal of Post Keynesianism Economics published by Taylor \& Francis: http://www.tandfonline.com/loi/mpke20

Accepted version made available via SOAS Research Online: http://eprints.soas.ac.uk/23081/

Veblen, T., (1904) The Theory of Business Enterprise New York: Charles Scribner's Sons. 